\title{
THE INHIBITION MILD STEEL CORROSION IN PHOSPHORIC ACID SOLUTIONS BY 2- PHENYL-1-HYDRAZINE CARBOXAMIDE
}

\author{
A. DADGARINEZHAD*, F. BAGHAEI
}

Materials Engineering Department, ShahiD Bahonar University, Kerman, Iran

(Received: July 15, 2008 - Accepted: April 24, 2009)

\begin{abstract}
In this work the effect of 2-phenyl-1-hydrazine carboxamide on the corrosion of mild steel in solutions of phosphoric acid $\left(\mathrm{H}_{3} \mathrm{PO}_{4}\right)$ has been investigated in relation to the concentration of the inhibitor and acid, by weight loss, potentiodynamic polarization, and AC impedance (EIS) measurements. Results obtained revealed that this compound is a good mixed -type inhibitor. Increasing the acid concentration increased the metal corrosion but did not affect on the inhibitor efficiency. The optimum inhibitor concentration remained $150 \mathrm{ppm}$ for various concentration of $\mathrm{H}_{3} \mathrm{PO}_{4}$. The surface morphologies of specimens after 1 hour of immersion in various solutions were studied by scanning electron microscopy (SEM).The Langmuir adsorption isotherm fitted well with the experimental data.
\end{abstract}

Keywords: Potentiodynamic; EIS; Inhibitor; SEM; Corrosion

\section{INTRODUCTION}

Phosphoric acid $\left(\mathrm{H}_{3} \mathrm{PO}_{4}\right)$ has many important uses, especially in the production of fertilizers. Most of the acid is produced from phosphate rocks by the wet process based on the reaction between phosphate rocks and acid solutions ${ }^{1}$.This acid $\left(\mathrm{H}_{3} \mathrm{PO}_{4}\right)$ is a medium-strong acid, but it is still shows strong corrosiveness on ferrous or ferrous alloys ${ }^{2}$. There is a great need to protect steel material used in the phosphoric acid industry from corrosion. Little work appears to have been done on the inhibition of steel in $\mathrm{H}_{3} \mathrm{PO}$ solutions $^{3-7}$. Most of the well-known acid inhibitors are organic compounds containing nitrogen, sulphur and oxygen atoms. Compounds with functional groups containing hetero-atoms which can donate lone pair electrons are found to be particularly useful as inhibitors for corrosion of metals ${ }^{2}$. Some organic compounds have been synthesized and investigated as inhibitors for corrosion of metals in acidic solutions ${ }^{8-13}$. The goal of the present work was to study the inhibition characteristics of 2- phenyl-1-hydrazine carboxamide as corrosion inhibitor for mild steel in $\mathrm{H}_{3} \mathrm{PO}_{4}$ using different techniques such as weight loss, potentiodynamic polarization and $\mathrm{AC}$ impedance spectroscopy.

\section{EXPERIMENTAL}

\section{Samples and solutions}

Mild steel specimens having percent composition of $0.05 \mathrm{C}, 0.65 \mathrm{Mn}$ $0.35 \mathrm{Si}, 0.01 \mathrm{~S}, 0.01 \mathrm{P}$ and remaining $\mathrm{Fe}$ were used. Surface of specimens was mechanically polished on wet $\mathrm{SiC}$ abrasive paper (grade 300-1200), rinsed with distilled water, degreased with absolute ethanol and dried at room temperature before using. All used materials were extra pure and solutions were prepared by using distilled water.

\section{Gravimetric studies}

The specimens were used for gravimetric measurement had a rectangular form $(1 \mathrm{~cm} \times 1 \mathrm{~cm} \times 0.1 \mathrm{~cm})$. The weight loss of specimens in various concentration of $\mathrm{H}_{3} \mathrm{PO}_{4}(1 \mathrm{M}, 2 \mathrm{M}, 3 \mathrm{M})$ with and without addition of different concentration of inhibitor after 1 hour of immersion period at $25^{\circ} \mathrm{C}$ was determined. The average three triplicate values was used according to the ASTM standard procedure described in literature ${ }^{14}$.

\section{Electrochemical measurements}

For electrochemical studies, the cell used was a conventional three electrodes Pyrex glass with a platinum counter electrode and a standard calomel electrode (SCE) as reference. The working electrode was embedded in Teflon so that its cross-sectional area $\left(1 \mathrm{~cm}^{2}\right)$ was in contact with the solution. The electrochemical impedance experiments were carried out using AC signals of amplitude $5 \mathrm{mV}$ peak to peak at the open circuit potential(OCP) in the frequency range $100 \mathrm{kHz}$ to $100 \mathrm{mHz}$ after $30 \mathrm{~min}$ immersion in the electrolyte cell. The impedance experiments were carried out with a Potentiostat/Galvanostat 263A (EG\&G) Princeton Applied Research HF response model 1025. PseudoPolarization curves were recorded with scanning rate of $1 \mathrm{mV} / \mathrm{s}$, after $30 \mathrm{~min}$ immersion from -700 to $0 \mathrm{mV}$ vs. $\mathrm{SCE}$ at room temperature.

Scanning electron microscopy

The surface microstructure of specimens after 1 hour of immersion in various

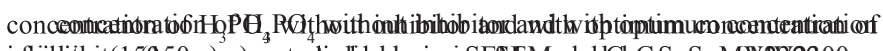

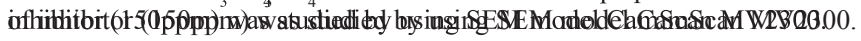

\section{RESULTS AND DISCUSSION}

Weight loss

The inhibition efficiency of inhibitor $\left(\mathrm{h}_{w} \%\right)$ in various concentration of acid $\left(\mathrm{H}_{3} \mathrm{PO}_{4}\right)$ was calculated as follows ${ }^{15}$.

$$
\eta_{w} \%=\frac{\Delta W_{0}-\Delta W}{\Delta W_{0}} \times 100
$$

Where $\Delta W_{0}$ and $\Delta W$ are the weight losses per unit area per time in the absence and presence of the inhibitor, respectively. The obtained data are summarized in table 1 .

Table 1. Inhibitor efficiencies obtained from weight loss measurement.

\begin{tabular}{|c|c|c|c|}
\hline \multicolumn{3}{|c|}{ Inhibition efficiency $(\% \eta)$} & \multirow{2}{*}{$\begin{array}{c}\text { Inh.conc. } \\
(\mathrm{ppm})\end{array}$} \\
\cline { 1 - 3 } $3 \mathrm{M} \mathrm{H}_{3} \mathrm{PO}_{4}$ & $2 \mathrm{M} \mathrm{H}_{3} \mathrm{PO}_{4}$ & $1 \mathrm{M} \mathrm{H}_{3} \mathrm{PO}_{4}$ & 50 \\
\hline 95.30 & 95.86 & 96.50 & 100 \\
\hline 96.50 & 97.50 & 97.88 & 150 \\
\hline 98.00 & 98.91 & 98.83 & 200 \\
\hline 97.50 & 98.93 & 98.98 & \\
\hline
\end{tabular}

Table 1 shows the variation of inhibition efficiency percent $(\mathrm{h} \%)$ with concentration of $\mathrm{H}_{3} \mathrm{PO}_{4}$ in presence and absence of various concentration of inhibitor. As seen, the inhibition efficiency increase with increasing inhibitor concentration to $150 \mathrm{ppm}$, in all

Concentration of acid and the maximum ( $\mathrm{h} \%$ ) was approximately $98.9 \%$.

\section{Potentiodynamic polarization}

fig 1 shows the polarization curves obtained for mild steel in various concentration of $\mathrm{H}_{3} \mathrm{PO}_{4}$ without inhibitor that indicated increasing mild steel corrosion by increasing acid concentration and fig2 shows polarization curves in $2 \mathrm{M} \mathrm{H}_{3} \mathrm{PO}_{4}$ without and with different concentration of inhibitor. It is clearly seen that this inhibitor shifted both the anodic and catholic branches of polarization curves of the pure acid solution to lower values of current density indicating the inhibition of the both hydrogen evolution (HER) and mild steel dissolution reactions. 


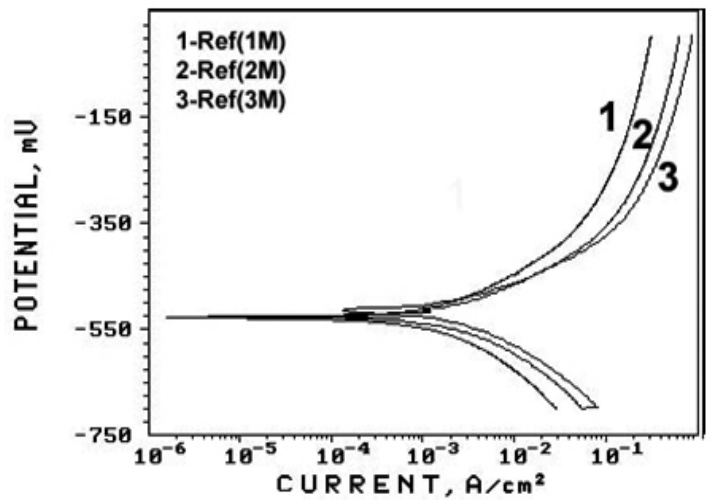

Fig 1. polarization curves in different concentration of $\mathrm{H}_{3} \mathrm{PO}_{4}$

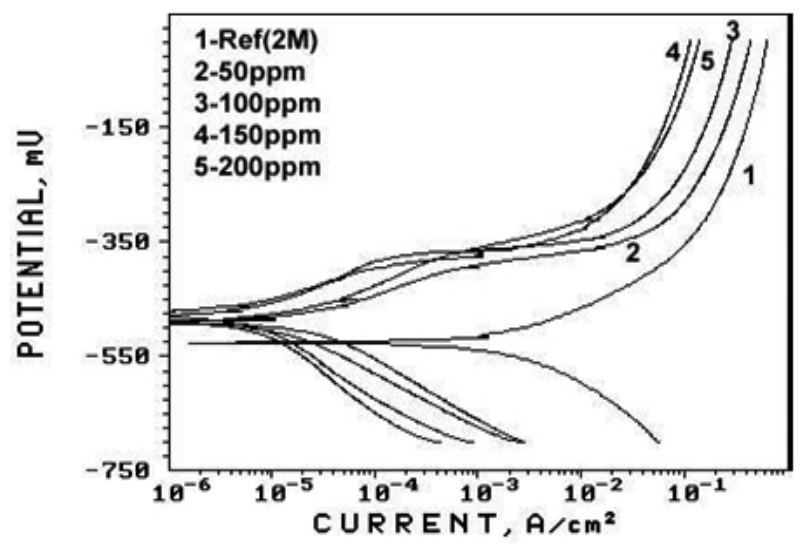

Fig 2. polarization curves in $2 \mathrm{M} \mathrm{H}_{3} \mathrm{PO}_{4}$ in absence and presence of various concentration of inhibitor.

Table 2 gives the obtained parameters from polarization curves. The inhibition efficiency ( $h \%$ ) of inhibitor was calculated by the follow equation

$$
\% \eta=\frac{I_{0}-I}{I_{0}} \times 100
$$

Table 2. polarization parameter values.

\begin{tabular}{|c|c|c|c|c|}
\hline$\% \eta$ & $\mathrm{I}_{\text {corr }} \mu \mathrm{A} / \mathrm{cm}^{2}$ & $\begin{array}{c}\mathrm{E}_{\text {corr }} \text { vs } \\
\mathrm{SCE} / \mathrm{mv}\end{array}$ & $\begin{array}{c}\text { Inh.conc/ } \\
\mathrm{ppm}\end{array}$ & $\begin{array}{c}\mathrm{H}_{3} \mathrm{PO}_{4} \\
\text { conc. }\end{array}$ \\
\hline- & 430.500 & -527.0 & 0 & $1 \mathrm{M}$ \\
99.20 & 3.439 & -480.6 & 150 & \\
\hline- & 567.900 & -525.3 & 0 & \\
96.1 & 22.140 & -492.3 & 50 & \\
98.0 & 11.358 & -484.3 & 100 & $2 \mathrm{M}$ \\
99.3 & 3.975 & -486.9 & 150 & \\
99.0 & 5.679 & -487.3 & 200 & \\
\hline- & 1103.000 & -517.0 & 0 & \\
99.1 & 9.927 & -474.5 & 150 & $3 \mathrm{M}$ \\
\hline & & & & \\
\hline
\end{tabular}

Where $\mathrm{I}_{0}$ and $\mathrm{I}$ are the uninhibited and inhibited corrosion current densities determined by extrapolation of catholic and anodic Tafel lines at $150 \mathrm{mV}$ more positive and negative than $\mathrm{E}_{\text {corr }}$.
Electrochemical impedance spectroscopy

Fig 3a shows the Nyquist plots of mild steel in $2 \mathrm{M} \mathrm{H}_{3} \mathrm{PO}_{4}$ without and with various concentration of inhibitor.
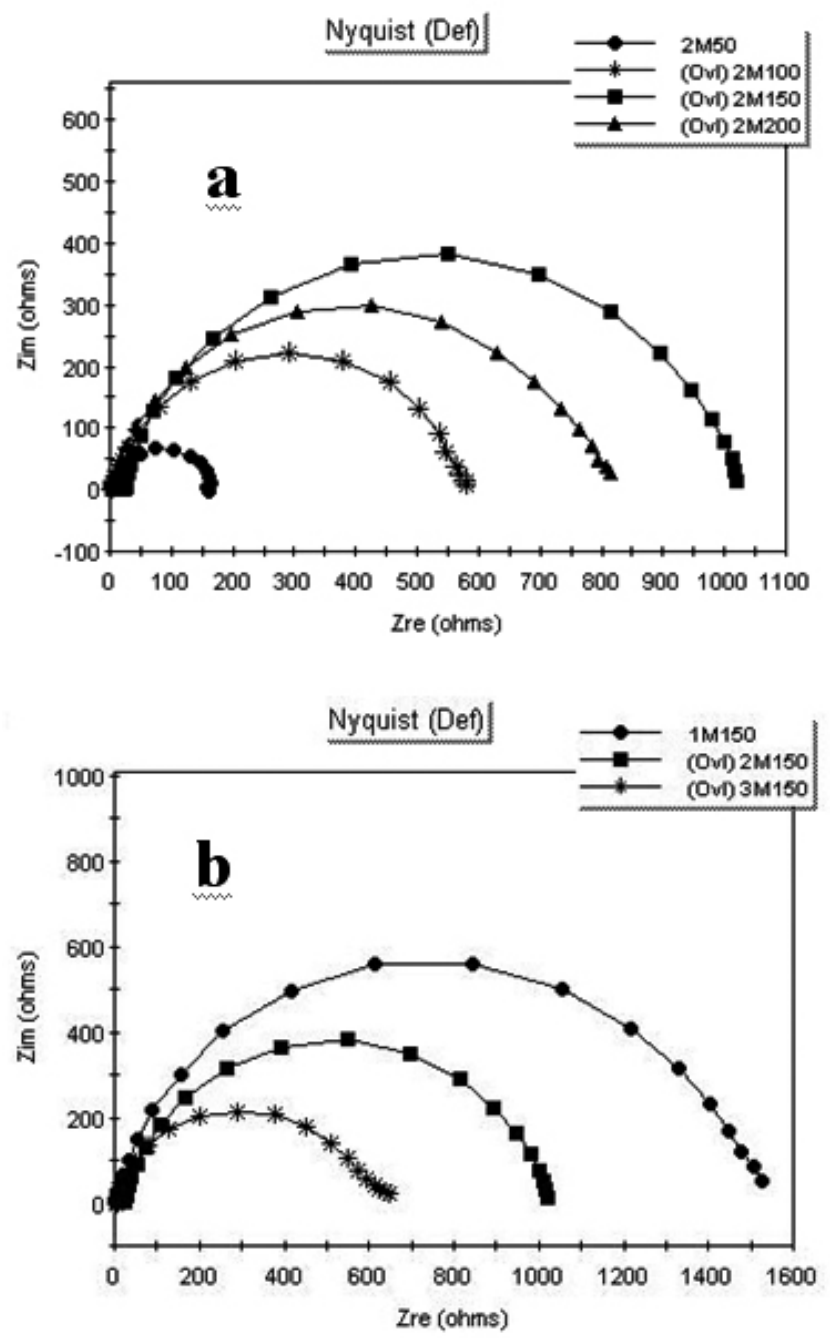

Fig 3. Nyquist plots.

a: in absence and presence of various concentration of inhibitor in $2 \mathrm{M}$ $\mathrm{H}_{3} \mathrm{PO}_{4}$.

b: in various concentration of $\mathrm{H}_{3} \mathrm{PO}_{4}$ and optimum concentration of inhibitor.

The charge transfer resistance $\left(\mathrm{R}_{\mathrm{c}}\right)$ values are calculated from the difference in impedance at lower and higher frequencies ${ }^{15}$. The double layer capacitance $\left(\mathrm{C}_{\mathrm{d} 1}\right)$ was obtained from the follows equation ${ }^{17}$.

$$
f\left(-Z_{\max }^{\pi}\right)=\frac{1}{2 \pi C_{d I} R_{t}}
$$

$\mathrm{F}$ is the frequency at the apex of the semicircle in the Nyquist plot. Fig.3b shows the Nyquist plots of mild steel in different concentration of $\mathrm{H}_{3} \mathrm{PO}$ with optimum concentration of inhibitor, it was found that by increasing the concentration of $\mathrm{H} \mathrm{PO}$, the mild steel corrosion was constant. The inhibition efficiency percent ( $\mathrm{h} \%$ ) of inhibitor is calculated by the follow equation ${ }^{18}$.

$$
\mathrm{h} \%=\frac{R_{c}-R_{0 c}}{R_{t}} \times 100
$$


Where $\mathrm{R}_{\mathrm{ct}}$ and $\mathrm{R}_{\mathrm{oct}}$ are the charge transfer resistance values with and without inhibitor, respectively. The impedance parameters derived from Nyquist plots are summarized in table 3 .

Table 3. obtained parameters from the Nyquist plots.

\begin{tabular}{|c|c|c|c|c|}
\hline$\% \eta$ & $\mathrm{C}_{\mathrm{dl}} / \mu \mathrm{Fcm}^{-2}$ & $\mathrm{R}_{\mathrm{ct}} / \mathrm{\Omega cm}^{2}$ & $\begin{array}{c}\text { Inh.conc/ } \\
\mathrm{ppm}\end{array}$ & $\begin{array}{c}\mathrm{H}_{3} \mathrm{PO}_{4} \\
\text { conc. }\end{array}$ \\
\hline- & 365.80 & 12.9 & 0 & \\
91.62 & 78.12 & 154.1 & 50 & \\
97.75 & 61.40 & 575.6 & 100 & \\
98.70 & 57.27 & 995.2 & 150 & $2 \mathrm{M}$ \\
98.40 & 73.25 & 811.0 & 200 & \\
\hline- & 270.30 & 35.5 & 0 & \\
97.67 & 55.91 & 1524.2 & 150 & $1 \mathrm{M}$ \\
\hline- & 388.90 & 8.6 & 0 & \\
98.66 & 64.45 & 643.1 & 150 & $3 \mathrm{M}$ \\
\hline
\end{tabular}

From the Nyquist parameter values it was found, that increasing $\mathrm{H}_{3} \mathrm{PO}_{4}$ concentration increases the mild steel corrosion respectively, and by increasing the inhibitor concentration increase $R_{c t}$ and decrease $C_{d l}$ values. It is due to the adsorption of inhibitor on the metal surfaces and leads to protective film formation ${ }^{19}$.

So it was found, that increasing concentration of $\mathrm{H}_{3} \mathrm{PO}_{4}$ did not affect on the inhibition efficiency of inhibitor, however, the optimum inhibitor concentration remained $150 \mathrm{ppm}$ for various concentration of $\mathrm{H}_{3} \mathrm{PO}_{4}$. This result was similar to the results observed from weight loss and potentiodynamic polarization methods.

\section{Scanning electron microscopy}

Micro structural studies of mild steel in various concentration of $\mathrm{H}_{3} \mathrm{PO}_{4}$ in absence and presence of optimum concentration of inhibitor were performed and were illustrated in fig.4.
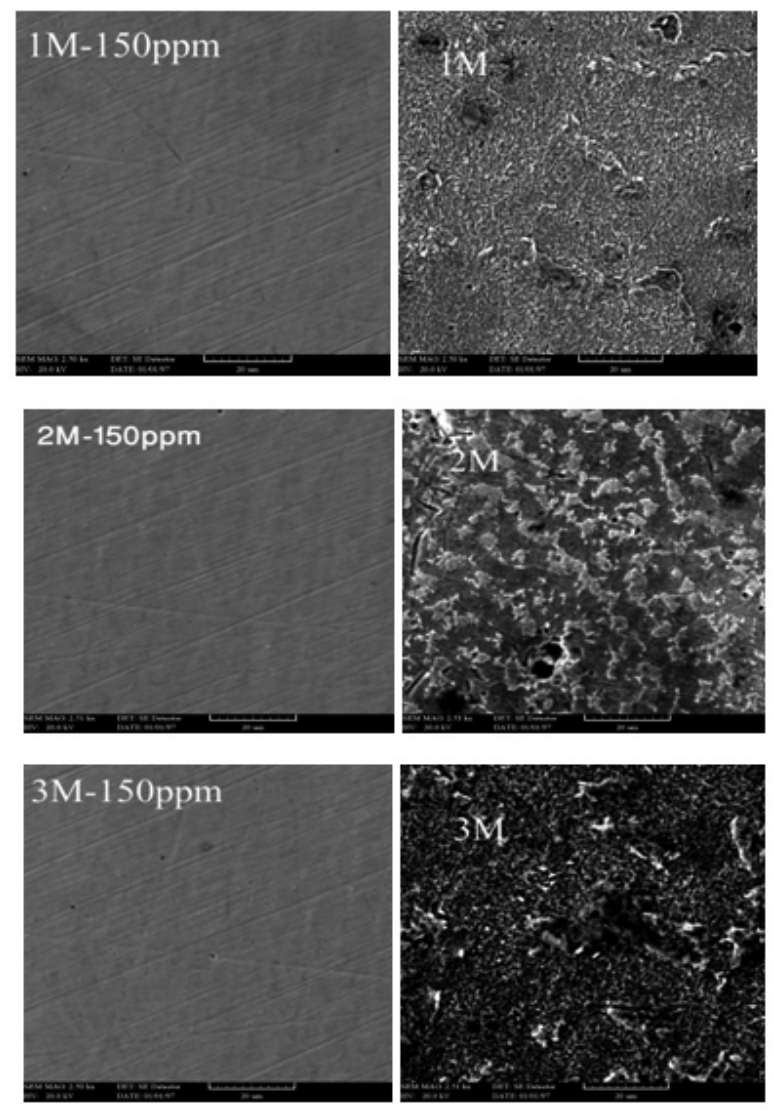

Fig 4. Surface features of mild steel exposed to various concentration of $\mathrm{H}_{3} \mathrm{PO}_{4}$ in absence and presence of optimum conc. of inhibitor.
It is clear that the corrosion attack was more pronounced in absence of the studied inhibitor, while the film formed on the metal surface becomes more protective, where the specimen surface is nearly intact as even the original polishing scratches are seen exposure.

\section{Adsorption isotherm}

The performance of the studied inhibitor (2- phenyl-1-hydrazine carboxamide) as a corrosion inhibitor may be attributed to the presence of electron donor groups (N,O and aromatic ring) in the molecular structure of inhibitor, which favors the greater adsorption of it on the metal surface ${ }^{20}$.

The unshared and $\mathbf{p}$ electrons interact with d-orbital of steel to provide a protective film ${ }^{21}$. To quantify the effect of inhibitor concentration on the corrosion rate, it is a common practice to fit the rate data to equilibrium adsorption expressions, such as the Langmuir equation ${ }^{22}$.

$$
\frac{C}{\theta}=\frac{1}{K_{a d s}}+C
$$

Where $\theta$ is the fraction surfaces coverage by the inhibitor and $\mathrm{K}_{\mathrm{ads}}$ is the equilibrium constant for the adsorption reaction:

$$
\theta=\frac{\eta \%}{100}
$$

The use of the Langmuir treatment is often justified with the argument that inhibition must involve adsorption. In this study, $\mathrm{C}_{\mathrm{inh}} \theta^{-1}$ is plotted against $\mathrm{C}_{\text {inh }}$, a linear relationship is obtained for each media indicating the Langmuir behavior (fig.5).
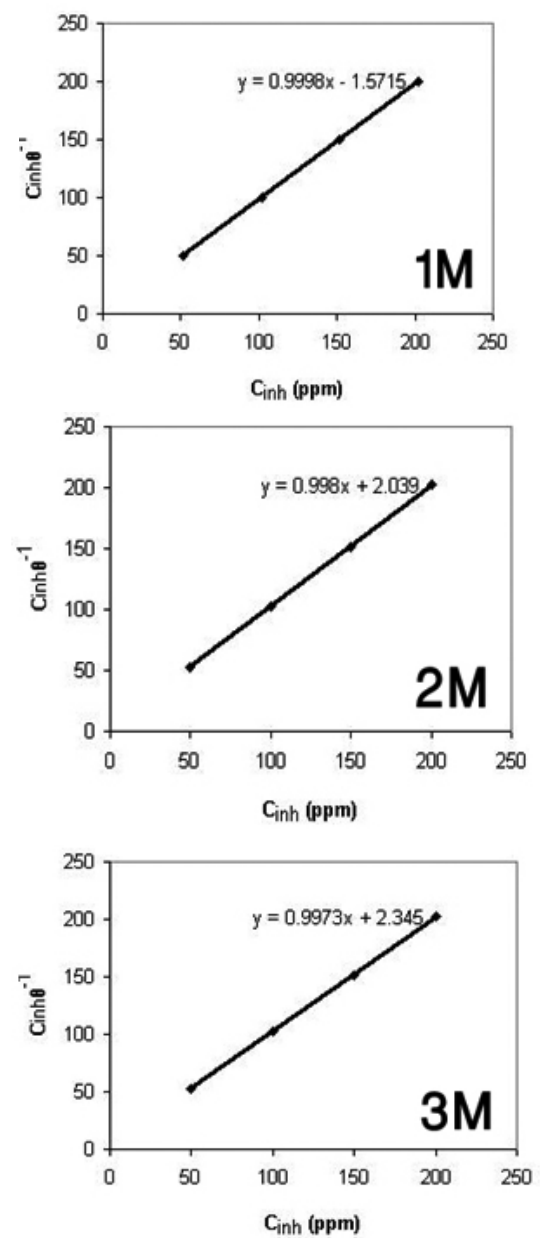

Fig.5. Langmuir plots for inhibitor on mild steel in various concentration of $\mathrm{H}_{3} \mathrm{PO}_{4}$ 


\section{CONCLUSIONS}

2-phenyl-1-hydrazine carboxamide was a good inhibitor for mild steel in $\mathrm{H} 3 \mathrm{PO} 4$ media.

This inhibitor acted as mixed inhibitor and maximum efficiency $(98 \%)$ attains an optimum value at $150 \mathrm{ppm}$ in $\mathrm{H}_{3} \mathrm{PO}_{4}$, and the acid concentration did not affect on the optimum efficiency of inhibitor.

The obtained results from different methods (EIS weight loss and polarization) were in good agreement.

The adsorption of inhibitor was consistent with a Langmuir isotherm model.

Micro structural studies elucidated a protective film on the metal surface in presence of inhibitor.

\section{REFERENCES}

1.- E. Khamis, M.A. Ameer, N.M.Alandis, and C. Al-Senai, Corrosion. Vol 56, NO.2, 127, (2000).

2.- Lin. Wang, Corrosion Science. 48, 608, (2006).

3.- Y. Jianguo, W. Lin, V. Oteno-Alego, D. P. Schweinsberg, Corrosion Sci. 37. 6, 973, (1995).

4.- S. J. Zakavi,C. N. Mehta, J. Electrochem. Soc. India, 37, 237, (1988).

5.- A. S. Fouda, H. A. Mostafa, Y. M. Darwish, M. N. Moussa, Bull. Soc. Chim, 2, 261, (1987).

6.- S. Hettiarachchi, Y. M. Chan, R. B. Wilson, V. S. Agarwalu, Corrosion .45, 30, (1989).
7.- B. Mernari, H. Elattari M. Traisnel, F. Bentis, M. Lagrence, Corros. Sci. 40, 391, (1998).

8.- C. Varalakshmi, B. V. Appa Rao, Anti-Corros. Methods \&Mater. 48.3, $171,(2001)$.

9.- M. A. Quraish, D. Jamal, Mater. Chem. Phys, 68(1-3), 283, (2001).

10.- S. EI Hajjaji, A. Lgamri, D. Aziane, A. Cuenbour, E. M. Essassi, M. Akssira, A. Ben Bachir, Prog. Org. Coat, 38(3-4), 207, (2000).

11.- F. Bentiss, M. Lagrenee, M. Trasinel, B. Mernari, H. Elattari, J. Appl. Electrochem, 29(9), 1073, (1999).

12.- M. Ei Achouri, S. Kertit, M. Salem, B. M. Essassi, M. Jellal, Bull. Electrochem, 14(12), 462, (1998).

13.- A. M. S. Abdennabi, A.l. Abdulhadi, S.T. Abu-oradi, H. Saricimen, Corros. Sci, 38, 1791, (1996).

14.- ASTM, Standard Practice for Laboratory Immersion Corrosion Testing of Metals, G31-72, 401, 1990

15.- T. Tsuru, S. Hunuyama, C. Boshoku, J. Japan Soc. Corros. Engg, 27, 573, (1987).

16.- M. Hosseini, S. F. L. Mertens, M. C. Chorbani, M. R. Arshadi, Materials Chemistry and Physics, 9647, (2002).

17.- F. Bentiss, M. Traisnel, M. Lagrence, Corros. Sci, 42, 127, (2000).

18.-Z-Quan, S. Chem, Y.Li, X.cui, Corros.Sci, 44, 703, (2002).

19.- L. Elkadi, Me. Mari, B.M.F. Traisnel, Bentiss, M. Lagrence, Corros.Sci, 42, 703, (2000).

20.- S. Kertit, B. Hummouti, Applied Surface Science, 93, 59, (1996).

21.- S. Kertit, K. Bekkouch, B. Hamouti Metallurgie- Cit, 251, (1998).

22.- M. Abdullah, Corrosion Science, 44, 717, (2002). 